\title{
A PHILOSOPHICALLY ENRICHED EXEGESIS OF CRIMINAL ACCESSORIAL LIABILITY
}

\author{
Mark Dsouza*
}

Abstract: The central features of the English criminal law's approach to the liability of principal offender are fairly clear, coherent, and settled. By contrast, the English law of criminal accessorial liability is notoriously lacking in these qualities. In this paper, I attempt to correct this imbalance by developing a philosophically enriched exegesis (and where appropriate, critique) of the English law on criminal accessorial liability, by reference to the structures of responsibility underpinning English criminal law. I take the relatively settled state of the English criminal law of principal liability to suggest that it is a good guide to these underlying structures. Therefore, using these rules (as adjusted for the differences in context between liability as a principal and liability as an accessory) as a template, I evaluate the English law of criminal accessorial liability.

\section{A. INTRODUCTION}

English criminal law has different sets of rules to govern liability as a principal offender, and liability as an accessory, but they both deal with the same essential subject-prima facie criminal responsibility, ie criminal responsibility, subject to available defences. We would expect a mature criminal law (like that of England and Wales) to be a coherent single system, characterised by internal consistency in the approaches it adopts to similar subjects at least in core matters. Accordingly, we would also expect its approach to liability as a principal offender and as an accessory to be similar, and similarly well understood.

The central features of the English criminal law's approach to liability as a principal offender are, notwithstanding some inevitable disputes about matters of detail, relatively clear, internally coherent, and uncontroversial. By contrast, the English approach to criminal accessorial liability is notoriously lacking in conceptual coherence. ${ }^{1}$ It is often criticised for being too inconsistent, confused, complicated, ${ }^{2}$ and equally, on some crucial matters, too simplistic. ${ }^{3}$ This is puzzling. It suggests that the two sets of rules have developed lopsidedly, with the former set being more likely to have developed in a principled manner.

In this paper, I attempt to correct this imbalance by developing a philosophically enriched exegesis (and where appropriate, critique) of the English law on criminal accessorial

\footnotetext{
* Lecturer, Faculty of Laws, University College London. I am grateful to Jonathan Rogers, Paul S Davies, Findlay Stark, Matt Gibson and the reviewers who read this paper for their comments and suggestions. Part of the research for this paper was carried out during my stint as a visiting scholar at the Centre for Penal Theory and Penal Ethics, University of Cambridge.

1 Andrew Ashworth, Principles of Criminal Law (5th edn, OUP 2006) 440; Keith JM Smith, A Modern Treatise on the Law of Complicity (Clarendon 1991) 4; DN Husak, 'Abetting a Crime' (2013) 33 L \& Phil 41, 44.

2 Graham Virgo, 'Making Sense of Accessorial Liability' (2006) Arch News 6; William Wilson and David Ormerod, 'Simply Harsh to Fairly Simple: Joint Enterprise Reform' (2015) Crim LR 3.

3 See Joshua Dressler, 'Reassessing the Theoretical Underpinnings of Accomplice Liability: New Solutions to an Old Problem' (1985) 37 Hastings LJ 91, 113; Beatrice Krebs, 'Mens Rea in Joint Enterprise: A Role for Endorsement?' (2015) CLJ 480; Michael Heyman, 'Losing All Sense of Just Proportion: The Peculiar Law of Accomplice Liability’ (2013) 87 St John's L Rev 129, 136.
} 
liability, by reference to the structures of responsibility underpinning English criminal law. I take it from the relatively settled state of the English criminal law's rules on the liability of principal offenders that they are fairly consistent with these underlying structures. Therefore, these rules (as adjusted for the differences in context between liability as a principal and liability as an accessory) are the yardsticks by reference to which I evaluate the rules on criminal accessorial liability.

I do this in two stages: first, I consider the rules regarding the attribution of a proscribed occurrence to an agent. Next, I discuss the rules relating to how we judge the said agent in respect of that occurrence. Finally, I demonstrate that the model of accessorial liability suggested by my findings generates plausible liability outcomes, and additionally, highlights areas in which doctrinal reform is needed. In particular, I will argue that we have positive reason to convict accessories of variegated offences, depending on their personal commitment to bringing about the proscribed occurrence, and that despite judicial suggestions to the contrary, one cannot be an accessory to another's offence if one had no influence on the latter's offending.

\section{B. THE FRAMEWORK OF CRIMINAL RESPONSIBILITY}

Although the term 'responsibility' is used in several different ways in moral discourse, ${ }^{4}$ criminal responsibility relates to judging a morally competent agent retrospectively for something done-for instance by asserting that the agent did it, and that the agent should be blamed or praised for doing it. ${ }^{5}$ In general, to hold an agent ' $\mathrm{D}$ ' retrospectively criminally responsible for an occurrence ' $\alpha$ ', we must show at least three things:

1. Occurrence-that the external manifestations of the actus reus, $\alpha$ happened;

2. Attributability-that $\mathrm{D}$ brought about $\alpha$-that is, that $\alpha$ can be attributed to $\mathrm{D}$; and

3. Accountability-that $\mathrm{D}$ was culpable in respect of bringing about $\alpha$.

The occurrence will invariably involve some conduct, perhaps performed in specified circumstances, and will sometimes also require some consequence to ensue. Since this paper is concerned primarily with responsibility, for the most part I will assume throughout that the 'occurrence', $\alpha$, has occurred.

Attributability and accountability appear at first glance to overlap. After all, if $\alpha$ is attributable to D, then isn't D accountable for the happening of $\alpha$ ? In fact, at least in the sense that I use these terms, there is no overlap.

\footnotetext{
4 See generally Andrew Eshleman, 'Moral Responsibility' in Edward Zalta (ed), The Stanford Encyclopedia of Philosophy (Summer 2014 Edition), <http://plato.stanford.edu/archives/sum2014/entries/moralresponsibility/> accessed 22 January 2019.

5 Thomas Michael Scanlon, What We Owe to Each Other (HUP 1998) 267-277.
} 
Attributability is concerned solely with identifying the persons who may properly be called the authors of an occurrence. A person who brings about $\alpha$ by her voluntary action, authors $\alpha$, and so she is responsible, in the attributability sense, for doing or causing $\alpha{ }^{6}$ Attributability responsibility is the difference between our judgments when we see one footballer head in a goal, and the football rebound off the head of another into the goal. We attribute the former goal to the footballer, and the latter to luck.

Once an occurrence has correctly been attributed to an agent, we may call her to account for bringing it about. We may, depending on the quality of the occurrence and the agent's explanation for bringing it about, find that she deserves praise or blame (or neither) in respect of it. In the context of criminal responsibility, we are most concerned with blaming judgments (although judgments of praiseworthiness and value-neutrality also affect the entitlement to certain defences). An agent's criminal culpability depends on her mens rea while acting and her explanation of why she chose to so act. In either case, the evaluation of criminal culpability or accountability is premised on a prior determination that the occurrence concerned was properly attributed to her.

These are, in outline, the general preconditions for holding D criminally liable for $\alpha$. On the assumption that $\alpha$ has occurred, I will, in what follows, show how this framework has been developed in the context of D's liability as a principal, and examine the extent to which the corresponding development of the law on D's liability as an accessory is consistent.

\section{Attribution ReSPONSIBILITY}

I start with attribution responsibility. To properly identify a morally competent agent, D, as a person to whom $\alpha$ may be attributed, we must first identify a voluntary act ${ }^{7}$ performed by $\mathrm{D}$ (perhaps in specified circumstances). Where the offence involved is a conduct crime-one for which no consequence ensuing from the conduct needs to be demonstrated-nothing further is required. However, in consequence crimes-where an element of $\alpha$ is that the conduct must give rise to certain consequences-we must show that D's voluntary act influenced the consequence.

I will not dwell on the voluntary act requirement here. There are no significant doctrinal divergences in how this requirement is fleshed out for liability as a principal and

\footnotetext{
6 Watson argues that coercion or duress negates attributability. Gary Watson, 'Two Faces of Responsibility' in Agency and Answerability: Selected Essays (OUP 2004) 260, 270-1. Whether or not this is a useful way to understand attributability, it is not how I use the term. My usage is closer to Hruschka's (he prefers the label 'First Level Imputation') and Scanlon's. See Joachim Hruschka, 'Imputation' (1986) BYU L Rev 669, 682-4; and Scanlon (n 5) 248-9, 273-80.

7 Or, where there is a duty to act, a voluntary omission. For convenience, I do not repeat this qualification of the act requirement hereinafter.
} 
liability as an accessory, and this requirement is not especially controversial in the context of accessorial liability. Suffice it to say that voluntariness allows us to link the external manifestations of a person's movements (the twitching of a finger, the swinging of an arm, and so on) to the person herself. Voluntariness turns a person's motion into her conduct, rather than something that happened to her. ${ }^{8}$

Influence allows us to link a person's voluntary acts to proscribed consequences. ${ }^{9}$ If we can show that D's movement was her conduct, and that it influenced the consequence, then $\mathrm{D}$ is answerable for the consequence. Whether $\mathrm{D}$ is found to be praiseworthy, blameworthy, or neither, depends on the answer that she proffers, but it is legitimate to ask D to answer for the consequences of her voluntary conduct, because we can attribute those consequences to her. Accessorial liability only attaches to D when some other person directly perpetrates a criminal act that is connected in some way to D's conduct. In that sense, it is akin to a consequence crime, where the direct perpetrator's criminal conduct is the consequence, even though it is not framed as such. Therefore, this factor-influence-is of especial interest in the context of accessorial liability.

The rules governing the attribution of consequences to an agent such that she must answer for them in criminal proceedings as a direct perpetrator ${ }^{10}$ require us to show a particular kind of influence, viz causation. Doctrinally, this requires us to establish both factual $^{11}$ and legal ${ }^{12}$ causation.

The position is somewhat different in respect of the attribution of an occurrence to an agent as a secondary party. It seems natural to suppose that a secondary party's link to the occurrence may be more tenuous than that of the direct perpetrator. But there is considerable disagreement amongst theorists about the exact kind of influence required to connect $\alpha$ to a person being tried as an accessory to bringing about $\alpha .^{13}$

8 See AP Simester, 'On the So-Called Requirement for Voluntary Action' (1998) Buff Crim L Rev 403, 406, $412-3$.

9 Theorists disagree on exactly what manner of connection to the proscribed occurrence is required. Dressler (n 3) 124-34 insists that both for principals and accessories, causation links the occurrence to the agent, whereas Sanford H Kadish, 'Complicity, Cause and Blame: A Study in the Interpretation of Doctrine' (1985) $73 \mathrm{Cal}$ L Rev 323, 354 identifies 'authorisation' as the linking factor in respect of accessorial liability. Neither suggestion captures the English doctrinal position. See connectedly Michael S Moore, 'Causing, Aiding, and the Superfluity of Accomplice Liability' (2007) 156 U Pennsylvania L Rev 395, 407, 432-440. I make my own suggestions later in this paper, but for now I use the neutral term 'influence' to signpost the need for some connection.

${ }^{10}$ I use the liability-neutral terms 'direct perpetrator' and 'secondary party' in preference to 'principal' and 'accessory' at this stage, since attribution itself does not imply even prima facie criminal liability. It is only after considering accountability that we can ascertain whether a defendant is even prima facie criminally liable.

${ }^{11} R v$ White [1910] 2 KB 124.

${ }^{12} R v$ Kimsey [1996] Crim LR 35; $R$ v Cato [1976] 1 All ER 260.

${ }^{13}$ Compare Kadish (n 9) 356-61 with Christopher Kutz, 'The Philosophical Foundations of Complicity Law' in John Deigh and David Dolinko (eds), The Oxford Handbook of Philosophy of Criminal Law (OUP 2011) 164, 
The doctrinal position is slightly clearer. While factual causation will obviously suffice, it is not essential for attributing $\alpha$ to $\mathrm{D}$ as a secondary party. ${ }^{14} \mathrm{D}$ may be an accessory even if $\mathrm{P}$ would have committed the same offence at the same time and in the same way without D's intervention. In some cases, this is because D's contribution, though not a sufficient or necessary cause, is a concurrent cause. Consider for instance Wilcox $v$ Jeffery. ${ }^{15}$ $\mathrm{D}$, a music critic, knowing that American saxophonist ' $\mathrm{P}$ ' was not permitted under his visa to perform at a ticketed show in England, bought a ticket to, attended, and reviewed P's performance. He was convicted as an accessory to P's offence even though there was no evidence that $\mathrm{P}$ knew that $\mathrm{D}$ would be present in the audience, or that $\mathrm{P}$ would not have performed if D had not bought a ticket or attended. D's contribution to P's offence was neither a sufficient nor necessary cause of P's offence. Nevertheless, as Moore demonstrates, ${ }^{16} \mathrm{D}$ was a cause of P's offence. Presumably, the presence of at least a small audience was a necessary condition for the performance to go ahead. Even though there would have been a sufficient audience without D, D contributed to there being an audience. No member of the audience was individually a sufficient or necessary cause-if one or a few individuals had not attended, the show would have gone on. However, if a sufficiently large number of them had not attended, the show would presumably have been cancelled. Hence each individual who attended was a concurrent cause of the performance. Whether this causal contribution was substantial was a separate matter. Since the other members of the audience were not also prosecuted, presumably the fact that D wrote a glowing review of P's performance was taken to elevate his contribution from insubstantial to substantial.

Additionally, in some cases, $\alpha$ may be attributed to D as a secondary party even though D was not a concurrent (let alone, sufficient or necessary) cause of $\alpha$. Consider D who, unknown to P, decides to act as P's lookout while P commits a burglary. D is never required to raise an alarm, and $\mathrm{P}$ commits the burglary exactly as she planned to anyway, being completely oblivious to D's presence. Or consider Tally, ${ }^{17}$ where the court held that when $\mathrm{D}$ prevented a warning telegram from being delivered to ' $\mathrm{V}$ ', he became an accomplice to P's murder of V, whether or not it could be proved that receipt of the telegram would have saved V's life. ${ }^{18}$ It was not necessary to show that D was a sufficient, necessary, or even concurrent cause of V's death. Even in such cases, as Moore demonstrates, D's actions do

Dressler (n 3) 99, 102, and Moore, Causing (n 9) 432-40.

${ }^{14} R v$ Calhaem [1985] QB 808; $R$ v Bryce [2004] EWCA Crim 1231, [2004] 2 Cr App R 35. Cf. $R v$ Mendez [2010] EWCA Crim 516, [2011] QB 876 [18]-[23].

15 (1951) 1 All ER 464.

${ }^{16}$ Moore, Causing (n 9) 423-4.

17 State v Tally (1894) 102 Ala 25.

18 ibid 738-9. 
exert some influence on $\alpha$ in that they raise the chances that $\alpha$ will occur. ${ }^{19}$ Moore argues that 'chance-raising' should be an independent desert basis, and that D should be convicted for raising the chances of $\alpha$ happening, even if $\alpha$ does not actually transpire. In effect he argues for converting accomplice liability in such cases into inchoate liability. ${ }^{20}$ But even without this new inchoate offence, Moore's argument allows us to connect D's conduct to the actual occurrence of $\alpha$, and therefore supplies a basis for attributing $\alpha$ to D. I would, however, add one caveat. I doubt we need to show that D's actions raised the chances of $\alpha$. Presumably even if D's inept efforts to help P bring about $\alpha$ actually reduced the chances of $\alpha$ happening, but in fact $\alpha$ did occur, D should be an accessory. Hence if the volunteer lookout in our hypothetical example foolishly wore a balaclava while standing outside the premises being burgled ('... because that's how criminals dress, right?'), and thereby unwittingly made it more likely for P's crime in progress to attract attention, she would still be an accessory to P's offence. Hence chance-raising is not needed to connect D to $\alpha$-chance-influencing suffices. What's more, when deciding whether $\alpha$ can be attributed to $\mathrm{D}$ as a secondary party, it is irrelevant whether D intended to influence the chances of $\alpha$ happening. This should not surprise. $\mathrm{P}$ can be attributed responsibility as a direct perpetrator for the unwitting and unforeseen consequences of his actions as well as the intended, or risked consequences thereof. I will argue that the agent's mental attitude to influencing $\alpha$ is relevant only when determining her accountability responsibility.

When D's actions have no influence-causal or chance-influencing-whatsoever on $\alpha$, there is no principled basis to attribute $\alpha$ to $\mathrm{D}$, even as a secondary party. This is true even if D makes all efforts to inveigle herself into P's $\alpha$-causing conduct. Therefore someone who shouts words of encouragement but is not heard, or offers assistance by way of visual prompts but is not seen, remains unconnected to the ultimate occurrence despite her personal culpability. ${ }^{21}$

A separate question is whether the chain of causation between a secondary party and the proscribed occurrence is broken by the (often free, voluntary and informed) acts of the direct perpetrator. This concern arises in all but pure chance-influencing cases (in which the secondary party directly influences the occurrence), and cases in which the secondary party

\footnotetext{
${ }^{19}$ Moore, Causing (n 9) 432-42. See also Keith JM Smith, 'The Law Commission Consultation Paper on Complicity: Part 1-A Blueprint for Rationalism' [1994] Crim LR 239, 244; R Antony Duff, 'Is Accomplice Liability Superfluous?' (2008) 156 U Pennsylvania L Rev PENNumbra 444.

${ }^{20}$ Moore, Causing (n 9) 442-52. See also Duff, Accomplice (n 19).

${ }^{21}$ Such personal culpability may well supply a basis for inchoate liability, but that is beyond the scope of this paper. English doctrinal law proceeds on the eminently plausible basis that there is value in assigning different labels to offenders, depending on whether or not they were the proximate agent exercising moral agency to bring about the proscribed occurrence through their voluntary actions. I cannot debate that premise in this paper, but for the present purposes, I too adopt it.
} 
procures a direct perpetrator to unwittingly commit a strict liability offence. ${ }^{22}$ It traces to the part of the novus actus interveniens rule ${ }^{23}$ which affirms our fundamental respect for the autonomy of individuals, whereby each person chooses her own actions and is responsible for those actions, but not the actions of others. Hence some theorists argue that accessorial liability is never premised on establishing a causal connection between the secondary party and the proscribed occurrence. ${ }^{24}$ Nevertheless, we accept that sometimes even human choices can be forced, ${ }^{25}$ and in those cases we 'relax' our commitment to the notion of individual autonomy. Clearly, the rule that an intervening agent's action breaks the chain of causation is not immutable, like a law of physics. Although doctrine stipulates that the free, voluntary, and informed act of an intervening agent breaks the chain of causation linking a person to the consequences of her actions as a direct perpetrator, in fact, humans influence the conduct of other humans all the time. What's more, even doctrine recognises this, and not just in the 'exceptions' to the novus actus interveniens rule. Defences like duress ${ }^{26}$ and loss of control ${ }^{27}$ also recognise that the actions of one person can cause another to react in a particular manner, and the criminal law's liability rulings are adjusted accordingly.

Perhaps then, as some theorists suggest, accessorial liability can also be conceptualised as an instance in which the criminal law recognises that causation can flow even through the free, voluntary, and informed actions of another. ${ }^{28}$ But Kadish disagrees. He argues that complicity liability relies on a separate complicity doctrine of attribution based not on any causal connection, but rather, on D's choice to accept responsibility for P's actions. ${ }^{29}$ For Kadish, D's choice is an expression of her autonomy which she exercises by choosing to accept responsibility for P's actions. Hence, in holding D responsible for P's actions, the law does not fail to recognise D's separate and autonomous agency; on the contrary, it gives effect to it. ${ }^{30}$ However, this view hardly reflects actual practice. People convicted as accessories rarely make such a choice, whether explicitly or implicitly. Perhaps they choose to associate with the principal in some criminal activity, but that is not the same as choosing to accept attribution responsibility for the principal's actions. A football supporter chooses to associate with her team in their on-field endeavours, but when the striker scores,

\footnotetext{
${ }^{22}$ Attorney-General's Reference (No. 1 of 1975) [1975] QB 773.

${ }^{23} R$ v Kennedy (No 2) [2007] UKHL 38, [2008] 1 AC 269; Kadish (n 9) 333, 355.

${ }^{24}$ Kadish (n 9) 355-61. See also Dressler (n 3) 109.

${ }^{25} R v$ Pagett (1983) 76 Cr App R 279.

${ }^{26} R v$ Martin (Colin) [1989] 1 All ER 652.

${ }^{27}$ Coroners and Justice Act 2009, ss 54-6.

${ }^{28}$ Moore, Causing (n 9) 408-12. See also Kutz (n 13) 154-55; FB Sayre, 'Criminal Responsibility for the Acts of Another' (1930) 43 Harv L Rev 689, 702, 707; Dressler (n 3) 126-28; Husak (n 1) 67-8.

${ }^{29}$ Kadish (n 9) 332-3, 354-55.

${ }^{30}$ ibid 354-5.
} 
the goal cannot in any meaningful sense be attributed to the supporter watching on television. What's more, the criminal law does not allow one to simply choose to take on the crimes of another. If Jesus expressed a desire to take on the sins of all defendants (past and present) in court, he should not expect to be visited with multiple convictions (whether in lieu of, or in addition to, the aforementioned defendants). As the term suggests attribution responsibility is attributed or assigned, not chosen or taken. ${ }^{31}$ Whereas a person's choices certainly influence her accountability responsibility-they are the basis for how she answers for the occurrencethese are not what makes her answerable for the occurrence. They do not, in other words, supply attribution responsibility. ${ }^{32}$ As I have already argued, accountability responsibility is premised on the prior establishment of attribution responsibility.

And this is the critical point. Attribution responsibility is separate from accountability responsibility, and both are essential for criminal liability as an accessory. ${ }^{33}$ Although one can only sensibly consider accountability responsibility once attribution responsibility has been established, neither form of responsibility can compensate for the absence of the other.

On balance, it appears that the requirements for attribution responsibility for secondary parties are broadly similar to those applicable to direct perpetrators. We must show that $\alpha$ occurred, and that it was connected to a voluntary act performed by the agent. There are of course differences in detail. Doctrine requires a direct causal connection to attribute $\alpha$ to an agent as a direct perpetrator, but does not insist on it in respect of secondary parties. Nevertheless, some influence is usually required as a precondition for attributing $\alpha$ to an agent as a secondary party as well. ${ }^{34}$ I have argued that an agent exerts such influence when she is a sufficient, necessary, or concurrent cause of $\alpha$, or she influences the chances of $\alpha$. Furthermore, this influence can also be exerted by influencing the conduct of others. These differences seem entirely appropriate, given that $\alpha$ is being attributed to the agent only as a secondary party, and not as a direct perpetrator. On the whole, therefore, the rules of attribution responsibility for direct perpetrators and secondary parties are happily compatible, and in line, with each other.

\section{ACCOUNTABILITY RESPONSIBILITY}

Once we have attributed an occurrence to an agent, and only then, may we call her to account for the occurrence. At this stage, we evaluate whether she deserves (moral) condemnation,

\footnotetext{
${ }^{31}$ HLA Hart, 'The Ascription of Responsibility and Rights' (1949) 49 Proceedings of the Aristotelian Society 171; Claire Finkelstein, 'Responsibility for Unintended Consequences' (2005) 2 Ohio St J Crim L 579, 582.

32 The converse is also true-factors like causation are relevant to attribution liability. Greater or lesser causation may expose an agent to more or fewer bases for accountability responsibility, but pace Dressler (n 3) 124-34, it cannot influence the extent of accountability responsibility for an occurrence attributed to the agent.

${ }_{33}^{3}$ pace Heyman (n 3).

${ }^{34}$ Moore, Causing (n 9). See also Duff, Accomplice Liability (n 19).
} 
praise, or value-neutral exoneration. The criminal law is most often concerned with making blaming or condemnatory judgments. It does so by assessing the defendant's culpability at two stages, viz, when determining prima facie liability for the crime, and when determining the availability of supervening defences. In this paper, I focus on culpability assessments relevant to establishing prima facie criminal liability.

The most plausible account of criminal blame is merit-based; we blame because some people deserve blame. They are culpable; that is blameworthy. ${ }^{35}$ But what makes an agent blameworthy? Several different theories compete on this point. The most prominent are premised on the defendant's choice ${ }^{36}$ and her character. ${ }^{37}$ The former account relies on the defendant's advertence to connect her wrongdoing to her qua moral agent, whereas the latter draws inferences about the defendant's character from her wrongdoing, and uses her character as a basis to blame the defendant qua moral agent. ${ }^{38}$

In this paper, I apply the choice-based exegesis and theory of criminal culpability that I started to develop in recent work. ${ }^{39}$ On this view, a defendant's in-principle culpability depends on her attitude towards the criminal law's advance normative guidance applicable in the circumstances as the defendant believed them to be. My preference for this theory does not limit my audience. Even character theories of criminal culpability accept that where advertent choice exists, this choice is the basis for blaming the defendant, ${ }^{40}$ and under English law one cannot inadvertently become an accessory. ${ }^{41}$ And while there are key differences between my preferred theory of culpability and competing choice-based theories, these do not affect the substance of the analysis that ensues. Hence a reader may reconstruct the ensuing argument in a manner compatible with her preferred account of culpability.

A person's advertent choices allow us to make inferences about her blameworthiness

${ }^{35}$ Eshleman (n 4). See also Mark Dsouza, 'Criminal Culpability After the Act' (2015) 26 KLJ 440.

${ }^{36}$ Michael S Moore, 'Choice, Character, and Excuse' (1990) 7(2) Soc Phil \& Pol'y 29; Michael S Moore and Heidi M Hurd, 'Punishing the Awkward, the Stupid, the Weak, and the Selfish: The Culpability of Negligence' (2011) 5 Crim L \& Phil 147, 172-3.

${ }^{37}$ Michael D Bayles, 'Character, Purpose and Criminal Responsibility' (1982) 1 L \& Phil 5; R Antony Duff, 'Choice, Character, and Criminal Liability' (1993) 12 L \& Phil 345; Victor Tadros, Criminal Responsibility (Oxford 2005); AP Simester, 'A Disintegrated Theory of Culpability' in Dennis J Baker and Jeremy Horder (eds), The Sanctity of Life and the Criminal Law (CUP 2013) 180, 183-5.

${ }^{38}$ For a summary see Dsouza (n 35) 443-6.

${ }^{39}$ Dsouza (n 35). The essential argument is that the criminal law operates in distinct temporal stages. First, the criminal law provides advance conduct guiding rules designed to minimise instances of occurrences identified as being worthy of proscription. Subsequently, if a proscribed occurrence nevertheless occurs, the in-principle 'ex post' culpability of the agent who brought it about ought to depend upon her attitude to the criminal law's advance conduct guidance, rather than to the proscribed occurrence.

${ }^{40}$ See Moore, Choice (n 36); Moore and Hurd, Punishing (n 36); Duff, Choice (n 37) 353, 359, 361-4; AP Simester, 'Responsibility for Inadvertent Acts' (2005) 2 Ohio St J Crim L 601, 603-4; Simester, Disintegrated (n 37) 185, 191.

${ }^{41} R v$ Webster [2006] EWCA Crim 415, [2006] 2 Cr App R 6; David Ormerod and Karl Laird, Smith, Hogan, and Ormerod's Criminal Law (15th edn, OUP 2018) 196; Heather M Keating and others, Clarkson and Keating: Criminal Law (8th edn, Sweet \& Maxwell 2014) 566. 
or praiseworthiness qua moral agent because those choices reflect the projects with which she aligns herself. An agent who aligns herself with noble projects is praiseworthy, and one who aligns herself with base projects is blameworthy. This sketch of how advertent choices enable us to find culpability in the chooser is accepted both by choice and character theorists. ${ }^{42}$ Let me call this the 'projects view' of inculpation.

According to my preferred theory of culpability, where the criminal law identifies $\alpha$ as an occurrence that should be criminally proscribed, it issues advance normative guidance designed to give effect to this proscription. $\alpha$ may contain elements of conduct, consequence, and circumstance, in various permutations and combinations. The criminal law's advance guidance pertains particularly to conduct. More specifically, it informs people about conduct that they should avoid so as not to fall foul of the criminal law's proscription of $\alpha$, either as a principal offender, or as an accessory. ${ }^{43}$

\section{Inculpation and direct perpetrators}

This bears some more explanation. Since it is easier to offer this explanation in relation to the law's conduct guidance on how to avoid being a principal offender, I do so in this section.

Assume that $\alpha$, the proscribed occurrence, has three elements to it-a conduct element ' $\alpha 1$ ', a circumstance element ' $\alpha 2$ ', and a consequence element ' $\alpha 3$ '. When the criminal law proscribes bringing about $\alpha$ intentionally or knowingly, the conduct guidance it offers members of the general public becomes applicable only when they know or intend that:

1. the circumstance element $\alpha 2$ exists or will exist when they engage in $\alpha 1$; and

2. the consequence element $\alpha 3$ will ensue if they engage in $\alpha 1$.

In those circumstances, they are guided not to engage in $\alpha 1$.

When the criminal law proscribes bringing about $\alpha$ recklessly, it issues conduct guidance to the general public (qua potential principal offenders) directing them not to engage in $\alpha 1$ if doing so might unreasonably risk causing $\alpha 3$ in circumstances of $\alpha 2$.

These abstractions of the criminal law's conduct guidance can be applied with modifications to different crimes whose actus reus stipulations may or may not have consequence or circumstance elements, and may also be adapted to apply to crimes with other mens rea requirements. For instance, consider the offence of criminally destroying or damaging property. ${ }^{44}$ This offence has certain circumstance elements (property, belonging to another), two alternative consequence elements (destruction of or damage to said property), and a conduct element (any causative conduct). Additionally, the offence will be satisfied by

\footnotetext{
${ }^{42}$ See for instance Finkelstein (n 31); Simester, Responsibility (n 40).

${ }^{43}$ Meir Dan-Cohen, 'Decision Rules and Conduct Rules: On Acoustic Separation in Criminal Law' (1984) 97(3) Harv L Rev 625; Paul H Robinson, 'Rules of Conduct and Principles of Adjudication' (1990) 57 U Chi L Rev $729,731-4$.

${ }^{44}$ Criminal Damage Act 1971, s 1(1).
} 
two alternative mens rea states, viz the intention to destroy or damage property which belongs to another, or recklessness as to whether property belonging to another would be damaged or destroyed. Hence the advance conduct guidance offered in relation to this offence to the general public (qua potential principal offenders) is,

If you know or intend that something is property, and that it belongs to another, and you know or intend that the conduct that you are contemplating will damage or destroy it, do not engage in that conduct. Additionally, do not engage in conduct that unreasonably risks destroying or damaging something that is property and that belongs to another.

Similarly, consider the offence of murder. This offence has a consequence element (the death) and two circumstance elements (the victim being a person, and being under the Queen's peace) in addition to a conduct element (any causative conduct). The offence will be satisfied by one of two alternative mens rea states, viz the intention to cause the death of a person, or the intention to cause grievous bodily harm to a person. The criminal law's conduct guidance to potential principal offenders in relation to proscribing the murder of $\mathrm{V}$ (a human) is,

If you know or intend that V is a person under the Queen's peace, and you know or intend that the conduct that you are contemplating will either cause $\mathrm{V}$ to die or suffer grievous bodily harm, do not engage in the conduct.

Likewise, consider rape. ${ }^{45}$ (With some simplification) this offence has a conduct element (penetration of a person's anus, vagina, or mouth with a penis) and a circumstance element (the absence of that person's consent). The mens rea for the offence is the intention to so penetrate and the absence of a reasonable belief that the other person is consenting. Hence the conduct guidance to potential principal offenders in relation to rape is,

If you are contemplating penetrating someone's anus, vagina, or mouth with a penis, and you have no belief (based on reasonable grounds) that such person is consenting, then do not penetrate that person.

In all of these examples, the criminalised occurrence $(\alpha)$ is the actus reus stipulation and the normative guidance to the direct perpetrator (which I will hereinafter call ' $\beta$ ') is the italicised statement of the criminal law's advance conduct guidance in relation to the offence. A person $(\mathrm{P})$ to whom $\alpha$ is attributable as a direct perpetrator is culpable for bringing about $\alpha$ if she advertently chooses not to be guided by $\beta$. If $\mathrm{P}$ 's failure to be guided by $\beta$ is inadvertent, she is not culpable for bringing about $\alpha$ (though she may or may not be culpable for bringing about some other proscribed occurrence) under the projects view.

\footnotetext{
${ }^{45}$ Sexual Offences Act 2003, s 1.
} 
Notice that while this explains P's inculpation in principle, it gives us no information about the extent of P's culpability or blameworthiness. In legal philosophy, culpability outcomes are usually ranked according to the agent's level of commitment to bringing about $\alpha{ }^{46}$ Hence, it is theoretically more culpable for $\mathrm{P}$ to make it her project to violate $\beta$ with the purpose of bringing about $\alpha$, than to do so without such purpose, even if she knows that by violating $\beta$ she will bring about $\alpha$. This, in turn, is more culpable than unreasonably choosing to violate $\beta$ knowing only of a risk that doing so might bring about $\alpha$. Doctrinally, we usually find the degrees of culpability stipulated in the offence definitions themselves. ${ }^{47}$ Invariably, where there are doctrinal hierarchies of culpability, these correspond with the theoretical hierarchy of culpability.

The foregoing synopsis of the projects view offers a serviceable explanation for accountability responsibility as a principal for one's advertent wrongdoing. As English law insists on advertence for accessorial liability, ${ }^{48}$ one would also expect the projects view to explain accountability responsibility for accessories. ${ }^{49}$ In what follows I consider the model of culpability that the projects view generates when applied to accessories, and the extent to which this diverges from doctrine.

\section{Secondary parties, their projects, and their liability for criminalised occurrences}

To test whether the projects view explains accountability responsibility for accessories as well as it did for principals, we must first identify the occurrence that the criminal law seeks to proscribe in relation to the accessory. This is relatively straightforward. Under English law, it is the same occurrence, $\alpha$, as is proscribed in relation to the principal. This is why both accessory and principal are convicted of crimes involving the same occurrence, be it the destruction of property belonging to another, or causing the death of a human, or subjecting another to non-consensual sexual intercourse.

What then is the criminal law's conduct guidance to parties to whom $\alpha$ is attributed as a secondary party? If $\beta$ represents the content of the criminal law's advance conduct guidance to the direct perpetrator $\mathrm{P}$, then for a secondary party $\mathrm{D}$ to be an accessory under the English accessorial liability rules:

1. D must do something (the conduct element) that either aids, abets, counsels, or procures $\mathrm{P}$ to engage in some conduct, and

\footnotetext{
${ }^{46}$ Douglas N Husak, 'The Sequential Principle of Relative Culpability' (1995) 1(4) LT 493; Miriam Gur-Arye, 'Human Dignity of "Offenders": A Limitation on Substantive Criminal Law' (2012) 6 Crim L \& Phil 187, 201; Krebs (n 3). See also Lord Mustill's comments in $R v$ Powell [1999] 1 AC 1, 11.

${ }^{47}$ Compare for instance the Offences Against the Person Act 1861, ss 18 and 20.

${ }^{48} R$ v Jogee [2016] UKSC 8, [2017] AC 387; Law Commission, Participating in Crime (Law Com No 305, 2007) paras B.69-74, Appendix A: Participating in Crime Bill, s 1(1)(a). Several scholars also defend this position at a theoretical level. See for instance, Heyman (n 3); Kutz (n 13); Kadish (n 9).

${ }^{49}$ For an example of analysis that proceeds on a similar basis, see Robinson (n 43) 734-36.
} 
2. P must engage in the said conduct (akin to a consequence element) and

3. D must intend by her own action to aid, abet, counsel, or procure the conduct of $\mathrm{P}^{50}$ and

4. D must intend or know ${ }^{51}$ that by engaging in such conduct $P$ would violate $\beta .{ }^{52}$

D's conduct guidance then is that if she is contemplating taking steps by which she intends to aid, abet, counsel, or procure $\mathrm{P}$ to engage in conduct, and she knows that P's conduct will violate $\beta$, she should not take those steps. When D makes it her project to flout this guidance, she is culpable in principle for bringing about $\alpha$.

So far, so good. Once again though, this explains D's inculpation in principle but gives no information about the extent of D's culpability or blameworthiness. As was the case with P, under the projects view, D's culpability should depend on her personal commitment to bringing about $\alpha$. D may set out to see that $\alpha$ happens, and take all the steps to get a previously ambivalent or reluctant $\mathrm{P}$ to bring about $\alpha$. Alternatively, she might enthusiastically agree with an equally enthusiastic $\mathrm{P}$ that $\mathrm{P}$ should bring about $\alpha$. She might also be persuaded or pressured, despite initial reluctance or ambivalence, to help $\mathrm{P}$ bring about $\alpha$. Or, she might be completely indifferent to whether or not $\alpha$ happens, and interested only in performing her part in something which she knows is designed to help P bring about $\alpha$. And so on. In each of these cases, D displays a different level of personal commitment to bringing about $\alpha$. One would expect $\mathrm{D}$ to be blamed accordingly, along a spectrum of accountability responsibility.

However, accessorial criminal liability under English law has a distinctly binary feel to it. Section 8 of the Accessories and Abettors Act 1861, which is the statutory basis for English doctrine on the subject, suggests that in general, one is either an accessory (and therefore liable to be tried, indicted, and punished as a principal offender), or not an accessory (and therefore liable to no punishment). Doctrinal law then diverges from what principle demands.

But one should not overstate the divergence. Some doctrinal middle ground is available. Where the same occurrence is stipulated as the actus reus of two or more separate offences with different mens rea states, English law is quite willing to convict direct perpetrators and secondary parties to the occurrence of different offences to better represent their respective culpabilities vis-à-vis the occurrence. Accordingly, the secondary party's

\footnotetext{
50 AP Simester and others, Simester and Sullivan's Criminal Law: Theory and Doctrine (6th edn, Hart 2016) 229-30; Smith, Hogan \& Ormerod (n 41) 197.

${ }^{51}$ Jogee (n 48).

52 There is some authority suggesting that one can be criminally liable for procuring the commission of a noncrime. $R v$ Cogan \& Leak [1976] QB 217; $R v$ Millward (1994) 158 JP 1091. Admittedly, this restatement of the conduct guidance in the law of accessorial liability does not accommodate that proposition of law. I explain why later in this paper.
} 
conviction may relate to an offence more ${ }^{53}$ or less $^{54}$ serious than that of the direct perpetrator. In fact, English law even permits the secondary party to an occurrence to be convicted as an accessory to an offence when the direct perpetrator has committed no offence. ${ }^{55}$

But even in respect of the very same offence, one could, in principle, conceive of gradations in accessorial liability. Germany for instance has two levels of liability for accessories to an offence, depending on how they are associated with the principal's offence. While aiding accomplices are convicted as 'facilitators' and given significant discounts from the sentences of their principals, inducing accessories are convicted as 'perpetrators' and given no such discount. ${ }^{56}$ Although the reasons for this distinction are rarely examined, ${ }^{57}$ they may relate to a perceived general difference in the culpabilities of inducing accessories and aiding accessories. ${ }^{58}$ There are also other theoretical models which gradate accessorial liability according to culpability levels. ${ }^{59}$

Plainly, D's commitment to bringing about $\alpha$ need not, in fact, be binary. D may set out to see that $\alpha$ happens, and take all steps to get a previously ambivalent or reluctant $\mathrm{P}$ to bring about $\alpha$. Alternatively, she might enthusiastically agree with an equally enthusiastic $\mathrm{P}$ that $\mathrm{P}$ should bring about $\alpha$. She might also be persuaded or pressured, despite initial reluctance or ambivalence, to help P bring about $\alpha$. Or, she might be completely indifferent to whether or not $\alpha$ happens, and interested only in performing her part in something which she knows is designed to help P bring about $\alpha$. And so on.

Since D's commitment to bringing about $\alpha$ may lie along a spectrum, it seems appropriate and principled that so too should her criminal liability. This notion is hardly alien to English criminal doctrine, being an essential element of the structure of liability for direct perpetrators. But the doctrinal law of accessorial liability provides for no such spectrum of liability.

Perhaps it should. Under a philosophically enriched model of accessorial liability incorporating a framework of accountability responsibility along the lines described above, liability outcomes would closely track accountability responsibility, and therefore generate fairer labelling and sentencing outcomes. In the next section I demonstrate how such a model would function.

\footnotetext{
${ }^{53} R v$ Howe [1987] AC 417.

${ }^{54} R v$ Stewart and Schofield [1995] 3 All ER 159; $R$ v Perman [1996] 1 Cr App R 24.

${ }^{55}$ Cogan (n 52); Millward (n 52). I mention these decisions without endorsing them, to illustrate the law's willingness to accept that principals and accessories may have differing culpability.

${ }^{56}$ Strafgesetzbuch s 26, s 27 and s 49(1). See also Markus D Dubber, 'Criminalizing Complicity' (2007) 5 J Int'1 Crim Just 977, 984; James G Stewart, 'Complicity' in MD Dubber and T Hornle (eds), The Oxford Handbook of Criminal Law (OUP 2014) 534, 540.

${ }^{57}$ Dubber (n 56) 984.

${ }^{58}$ See Stewart (n 56) 540.

${ }^{59}$ See for instance, Kutz (n 13) 152, 158, 161-4.
} 


\section{E. A PHILOSOPHICALLY ENRICHED MODEL OF ACCESSORIAL LIABILITY}

The philosophically enriched model I have in mind would incorporate the ideas about how attribution and accountability responsibility relate to accessorial liability, as discussed above. I will demonstrate how this model would function by explaining how it would deal with a variety of cases, real and hypothetical.

\section{Attributing an occurrence}

The first step in applying such a model is to identify the persons to whom an occurrence can be attributed, and the capacity in which it can be so attributed. Consider the following scenarios:

1. A morally competent agent $\mathrm{P}$ shoots $\mathrm{V}$ dead. No other party is involved. $\alpha$ (in this instance, V's death) can straightforwardly be attributed to $\mathrm{P}$ as the direct perpetrator.

2. A mob gathers to beat $\mathrm{V}$, and $\mathrm{V}$ dies from the cumulative effects of the blows. Each person that stuck $\mathrm{V}$ can be attributed $\alpha$ (V's death) as a direct perpetrator. ${ }^{60}$

3. D, an adult encourages $\mathrm{P}$, an infant, to shoplift. In this case, $\alpha$ (the shoplifting) is alienated completely from the putative direct perpetrator who is not a competent moral agent, and is instead attributed directly to $\mathrm{D}$ who made $\mathrm{P}$ bring it about. ${ }^{61}$

4. D deliberately misleads $\mathrm{P}$, a competent moral agent, to believe that she is doing something completely innocent, like giving $\mathrm{V}$ her medicine, ${ }^{62}$ or some fruit, ${ }^{63}$ when she is in fact poisoning $\mathrm{V}$ to death. In such cases, $\mathrm{D}$ is manipulating $\mathrm{P}$ as if $\mathrm{P}$ were a mere implement to be deployed in D's project. Recognising that fact, the legal fiction of 'innocent agency', attributes $\alpha$ (V's death) to D as the direct perpetrator, and not to P. P simply drops out of the picture.

In each of these cases, there is no party to whom $\alpha$ is attributed as a secondary party. Instead there are one or more direct perpetrators, and the standard rules of criminal accountability responsibility may be applied to determine whether, and to what extent, they are culpable. While that seems straightforward enough, it might be useful to briefly dwell on the 'innocent agency' doctrine as applied in case 4 above.

Some background first. When D uses a gun to shoot V, it is technically correct to say that both $\mathrm{D}$, and the gun, caused the injury to $\mathrm{V}$, but the criminal law is not concerned with holding the gun criminally responsible for V's injury. The same applies when D sets his dog on V-again, though technically both D and D's dog cause V's injuries, modern criminal law

\footnotetext{
${ }^{60}$ Moore, Causing (n 9) 422-4.

${ }^{61}$ See also the first two examples considered in Law Com No 305 (n 48) para 4.10.

${ }^{62} R$ v Michael (1840) 9 C \& P 356.

${ }^{63}$ The Queen $v$ Saunders and Archer (1575) 75 ER 706.
} 
does not try the dog. The criminal law's notion of attribution responsibility does not treat the gun or the dog as things to which responsibility for an occurrence may be attributed. They are not moral agents; instead, they are mere implements, being manipulated by $\mathrm{D}$ in the furtherance of D's own projects. Therefore, D is treated as the direct perpetrator (rather than as a secondary party).

When the 'implement' that D manipulates in pursuit of her project is actually another competent moral agent, the doctrine of innocent agency applies to create a deeming legal fiction $^{64}$ based on which we ignore the separate moral agency of the 'implement', and treat the manipulator as the principal. This fiction allows us to better identify the real independent causal agent(s) to whom an occurrence may be attributed. The innocent agent's conduct is attributed to the manipulator.

So far so good. However, some theorists argue that conduct like having sexual intercourse, marrying during the continuance of a previous marriage, lying under oath, being drunk in public, and selling liquor contrary to one's licence ${ }^{65}$ is 'nonproxyable' (that is, incapable of being attributed to someone other than the factual perpetrator). Their reasons are largely to do with the linguistic oddity of thinking of these kinds of conduct as proxyable. ${ }^{66}$ Although the idea of 'nonproxyability' has quietly passed into orthodoxy, the basis for its assimilation into the criminal law is fundamentally confused. I cannot fully defend my reasons for thinking so here, but I will outline them briefly. Admittedly, it sounds odd to hear that D had sexual intercourse through the agency of someone else, or 'remarried' through the agency of someone else and so on, but that is no grounds for thinking that the doctrine of innocent agency cannot apply. It sounds odd because it is odd-it is avowedly fiction. As with statutory fictions, when interpreting legal fictions, '[s]ometimes a big leap of imagination is required ${ }^{67}$ to give effect to the underlying policy intentions. So to see whether the fiction of innocent agency ought to be applied even in respect of these supposedly nonproxyable actions, we must consider the underlying policy. Or, to paraphrase Moore, ${ }^{68}$ we must ask what evil the criminal law is proscribing in offences like bigamy, public drunkenness, prison escapes, and rape. Is it the evil of being in an invalid marriage, being drunk in public, prisoners being outside the prison walls, and being subjected to sexual intercourse without consent respectively? Or is it the evil of getting oneself into an invalid marriage, getting

\footnotetext{
${ }^{64}$ pace Peter Alldridge, 'The Doctrine of Innocent Agency' (1990) 2 Crim L Forum 45, and Glanville Williams, 'Innocent Agency and Causation' (1992) 3 Crim L Forum 289, who dispute the need for such a fiction. I cannot join this debate here - suffice it to say that the doctrine and the fiction exists. See Simester \& Sullivan (n 50) 215; Clarkson \& Keating (n 41) 581.

${ }^{65}$ Kadish (n 9) 373-7; Law Com No 305 (n 48) paras B.19-20.

${ }^{66}$ Kadish (n 9) 373-77; Simester \& Sullivan (n 50) 216-7.

${ }^{67}$ O Jones, Bennion on Statutory Interpretation (6th edn, LexisNexis 2013) § 304.

${ }^{68}$ Moore, Causing (n 9) 419-20.
} 
oneself into a public place while drunk, prisoners getting themselves outside the prison walls, and personally engaging in sexual intercourse with a non-consenting person, respectively?

It seems to me that if we are trying to identify the proscribed occurrence-which I have referred to as ' $\alpha$ ' in the foregoing discussions-then the former set of answers is more apposite. ${ }^{69}$ The latter set of answers deals with the agent's culpability rather than the actual evil that the criminal law seeks to prevent. And if the former set of answers is correct, then the legal fiction of innocent agency should be given its full effect, despite the leap of imagination required to overcome the linguistic oddities of asserting that one can engage in conduct through the agency of another. Doing so would also help us avoid the doctrinal gymnastics involved in criminally convicting people for procuring the commission of noncrimes. ${ }^{70}$ What's more, although innocent agency is a legal fiction, it is not a fiction based in fantasy. Rather, it captures the very real underlying truth that the manipulator is the person truly responsible for the actions of the manipulated. The puppeteer is responsible for the movements of her puppet, and the 'fiction' in innocent agency lies simply in treating a metaphorical puppet as an actual puppet. A better view therefore, and one not radically inconsistent with doctrine, is that the innocent agency rule applies to all offences.

Let us consider now scenarios in which there is a secondary party.

5. D persuades a previously disinclined $P$ to kill $\mathrm{V}$, and $\mathrm{P}$ does. D's encouragement is a but-for cause of P's actions. $\alpha$ (V's death) may be attributed to $\mathrm{P}$ as the direct perpetrator and to $\mathrm{D}$ as a secondary party.

6. D encourages a previously undecided $\mathrm{P}$ to kill $\mathrm{V}$, and $\mathrm{P}$ does. Again, D's encouragement is a but-for cause of P's actions, and $\alpha$ (V's death) may be attributed to $\mathrm{P}$ as the direct perpetrator and to $\mathrm{D}$ as a secondary party.

7. $\mathrm{P}$ decides that if she attracts an adequate audience, she will illegally perform a concert. D joins the crowd of people watching $\mathrm{P}$, and $\mathrm{P}$ performs illegally. Even without $\mathrm{D}$, the crowd had been large enough for $\mathrm{P}^{71} \alpha$ (the illegal performance) can of course be attributed to $\mathrm{P}$ as the direct perpetrator. Additionally, although $\mathrm{D}$ is an insufficient and non-necessary cause of $\alpha$, she is a concurrent cause thereof, and so (subject to the de minimus rule) $\alpha$ can also be attributed to $\mathrm{D}$, as a secondary party.

\footnotetext{
${ }^{69}$ pace Moore, Causing (n 9), who refers to American doctrine in his discussion to support the latter set of answers. English doctrine however seems far more inclined in the opposite direction. For instance, the Law Commission, in Law Com No 305 ( $\mathrm{n}$ 48) para B.123, was willing to treat rape as a proxyable offence. Additionally, the court of appeal in Cogan (n 52) at 223-4 would have preferred to convict D as a principal acting though P's innocent agency in raping V, but could not, because D had been charged only as an accessory.

${ }^{70}$ See Cogan (n 52); Millward (n 52) in which courts held that one could somehow be an accessory to a noncrime. The Law Com No 305 (n 48) para B.24 criticised this dilution of basic principles of accessorial liability.

${ }^{71}$ Example adapted from the facts of Wilcox (n 15).
} 
8. Knowing of P's plans to steal from a safe, D tells $\mathrm{P}$ the safe's combination, which $\mathrm{P}$ uses to steal. D's assistance is a necessary cause of P's bringing about of $\alpha$ (the theft of property). So, while $\alpha$ is attributed to $\mathrm{P}$ as the direct perpetrator, it is also attributed to $\mathrm{D}$, as a secondary party.

9. P plans to shoot V dead and D, who knows of P's plan, also wants V to die. D knows (but P does not) that P's gun is jammed. D secretly repairs P's gun, and P then uses it to kill V. Here, $\alpha$ (V's death) is of course attributed to $\mathrm{P}$ as the direct perpetrator. It is also attributed to $\mathrm{D}$ as a secondary party because $\mathrm{D}$ is a necessary cause thereof.

10. P enters a shop to burgle. Her partner D stands guard outside, ready to raise the alarm if needed. P succeeds, and D never has to intervene. Here, even if one argues that D was not causally connected to $\alpha$ (the burglary), D's assistance did influence the chances of $\alpha$ occurring, and so while $\alpha$ is attributed to $\mathrm{P}$ as the direct perpetrator, it is also attributed to $\mathrm{D}$ as a secondary party.

11. P plans to break out of prison, and promises to pay $\mathrm{D}$ for her help. $\mathrm{D}$ is indifferent to P's success but wants the payment offered. She helps $\mathrm{P}$ by giving $\mathrm{P}$ diamond wire to cut the prison bars. P successfully escapes. ${ }^{72}$ Here, D's assistance was a necessary cause of $\alpha$ (the prison break), so while $\alpha$ is attributed to $\mathrm{P}$ as the direct perpetrator, it is also attributed to $\mathrm{D}$ as a secondary party.

12. P wants to go on an expedition to kill policemen. She forces $\mathrm{D}$, at gunpoint, to drive her on this expedition. The expedition 'succeeds'-P shoots policeman $\mathrm{V}$ dead. ${ }^{73} \mathrm{D}$ 's assistance made $\alpha$ (V's death) possible, so while $\alpha$ is attributed to $\mathrm{P}$ as the direct perpetrator, it is also attributable to $\mathrm{D}$ as a secondary party.

13. P asks D to sell her highly specialised 'oxygen cutting equipment', whose primary use is cutting through reinforced metal. D does not know the details of P's plans but recognises a significant risk that $\mathrm{P}$ will use the equipment for some illegal purpose. Nevertheless, she sells the equipment to $\mathrm{P} .{ }^{74} \mathrm{P}$ uses it to rob the bank. Here too D's assistance was a necessary cause of $\alpha$ (the bank robbery), so while $\alpha$ is attributed to $\mathrm{P}$ as the direct perpetrator, it is also attributable to $\mathrm{D}$ as a secondary party.

14. The facts are the same as in Case 13 except that $\mathrm{D}$ does not see the risk that $\mathrm{P}$ will use the equipment for an illegal purpose, although a reasonable person in her position would have seen it. Even so, D's assistance was a necessary cause of $\alpha$, and so while $\alpha$ is attributed to $\mathrm{P}$ as the direct perpetrator, it is also attributed to $\mathrm{D}$ as a secondary party.

\footnotetext{
${ }^{72}$ Example adapted from the facts of $R v$ Anderson [1986] AC 27.

${ }^{73}$ Example adapted from the facts of Lynch v DPP for Northern Ireland [1975] AC 653.

${ }^{74}$ Example adapted from the facts of $R v$ Bainbridge [1960] 1 QB 129.
} 
15. Again, the facts are the same as in Case 14, except that even reasonable persons in D's position would not have seen the risk that $\mathrm{P}$ would use the oxygen cutting equipment for an illegal purpose. Nevertheless, D's assistance was a necessary cause of $\alpha$, and so while $\alpha$ is attributed to $\mathrm{P}$ as the direct perpetrator, it is also attributed to $\mathrm{D}$ as a secondary party.

In all these cases, D's voluntary conduct influences $\alpha$ sufficiently for $\alpha$ to be attributable to D, albeit as a secondary party. Finally, consider some cases in which, despite initial appearances, there is no secondary party.

16. Seeing $\mathrm{P}$ about to attack V, D shouts encouragement to P. P, being deaf, does not hear D, but nevertheless injures V. $\alpha$ (V's injury) is attributed to $\mathrm{P}$ as the direct perpetrator, but it is not attributable to D in any capacity, because D does not influence it at all. ${ }^{75}$

17. Seeing $\mathrm{P}$ about to attack V, D shouts encouragement to $\mathrm{P}$. Even without any encouragement, P would have attacked V. As such D's words were completely ineffectual, and were not even concurrent causes of V's resulting injury. They did not influence the chances of V being injured either. For all the difference D's words made, D may as well have been praying to god for P to attack V. $\alpha$ (V's injury) is attributable to $\mathrm{P}$ as the direct perpetrator, but is not attributable to $\mathrm{D}$ in any capacity, because $\mathrm{D}$ does not influence it at all. ${ }^{76}$

In these cases, D may well be culpable in that D deliberately sets herself on a course of action that runs contrary to the criminal law's guiding norms. However, blameworthiness, while necessary for blame, is not sufficient for it. ${ }^{77} \mathrm{We}$ independently need D to have brought about something for which she can be blamed. D's blameworthiness cannot supply that; only attribution responsibility can, and that is not present.

\section{Accountability based on commitment to the criminal project}

Having attributed $\alpha$ to D we can now consider whether, and to what extent, D is accountable for $\alpha$. Since this paper is not about accountability responsibility for direct perpetrators, I will focus only on cases in which $\alpha$ is attributed to D as a secondary party.

I previously argued that as a secondary party, $\mathrm{D}$ is culpable in principle for bringing about $\alpha$ if, in effect, she advertently makes it her project to aid, abet, counsel, or procure $\mathrm{P}$ to act so as to violate $\beta$. Furthermore, in theory the extent of D's culpability should depend on

\footnotetext{
${ }^{75}$ Moore, Causing (n 9) 442-6, suggests inchoate, but not accessorial, liability for D in cases like this.

${ }^{76}$ See also Smith (n 19) 244. There is arguably some weak authority for the contrary position in $R v$ Giannetto [1997] 1 Cr App R 1, in which the Court of Appeal noted, without expressing approval or disapproval, the trial judge's obiter dicta assertion that $\mathrm{D}$ would be an accessory to $\mathrm{P}$ 's murder if, after $\mathrm{P}$ declared that he was going to kill V, D had patted P on the back or said 'Oh goody'. Even so, the Court's example does not make it clear that P did not derive some encouragement from D's statement. My argument is limited to cases in which D's actions do not influence $P$ at all.

${ }^{77}$ See Dsouza (n 35) 454-6.
} 
her commitment to bringing about $\alpha$. Hence D should be more culpable if she acted with the purpose of bringing about $\alpha$, than if she brought about $\alpha$ knowingly, but without it being her purpose to do so. Let us consider the liability outcomes that this approach to accessorial accountability responsibility would generate in cases 5 to 15 discussed above.

Consider first D's 'in-principle' culpability. In Cases 5 to 12, D intentionally does acts that she knows will either assist or encourage $\mathrm{P}$ to perform conduct by which she intends, or knows, that $\mathrm{P}$ will violate $\beta$. In Cases 5, 6 and 7, D's actions encourage P's conduct, and D intends for P's conduct to violate $\beta$. In Case $5, \mathrm{D}$ procures the violation of $\beta$ by $\mathrm{P}$ inasmuch as she intentionally sets out to make $\mathrm{P}$ violate $\beta$. In Case $6, \mathrm{D}$ counsels $\mathrm{P}$ by intentionally encouraging $\mathrm{P}$, in advance, to violate $\beta$. In Case $7, \mathrm{D}$ abets $\mathrm{P}$ by intentionally encouraging $\mathrm{P}$ to violate $\beta$, contemporaneously with the violation. In Cases 8, 9, and 10, D's actions aid P's conduct, and D intends for P's conduct to violate $\beta$. It is irrelevant to D's culpability that in Case $9 \mathrm{P}$ is unaware of D's assistance, and that in Case 10 D's assistance was, as it transpires, superfluous. We are concerned at this stage solely with D's accountability responsibility or culpability; the occurrence $\alpha$ has already been attributed to D. Hence in all of these cases, D is, in principle, culpable as an accessory to P's criminality. In Cases 11 and 12, D's actions aid $\mathrm{P}$ 's conduct, and although she does not want for $\mathrm{P}$ to thereby violate $\beta, \mathrm{D}$ knows that $\mathrm{P}$ will. Hence she fails to be appropriately guided by the criminal law's advance guidance to her-she intends to assist P's conduct despite knowing that it will violate $\beta$. Perhaps some defence of duress should be available to $\mathrm{D}$ in respect of Case 12, but that is beyond the scope of this paper. In all of these cases, D is culpable, in principle, as an accessory to P's crime.

In Cases 13, 14, and 15, D intentionally acts to aid P's conduct (using the oxygen cutting equipment on reinforced metal). In Case 13, D is subjectively aware of a risk (that is objectively unreasonable to take) that P's conduct will violate $\beta$. Until the Supreme Court's recent ruling that subjective recklessness as to whether P's conduct would amount to a criminal offence was insufficient to found accessorial liability, ${ }^{78}$ this would have been enough to make D culpable in principle as an accessory to P's crime. Now, it is not. In Cases 14 and 15 , $\mathrm{D}$ does not realise that $\mathrm{P}$ might, by engaging in the conduct assisted, violate $\beta$. In Case 14 , $\mathrm{D}$ is negligent in not so realising, and in Case 15, she is not. However, in neither case does she fail to be appropriately guided by the criminal law's advance guidance to her-that guidance is only violated when $\mathrm{D}$ acts despite knowing that her conduct would assist $\mathrm{P}$ to violate $\beta$. Hence, in Cases 13 to 15 , although $\alpha$ can be attributed to $D, D$ is not culpable in respect of the occurrence thereof. Indeed this is also the position in doctrine. ${ }^{79}$

\footnotetext{
78 Jogee (n 48).

${ }^{79}$ Bryce (n 14). See also Simester \& Sullivan (n 50) 235-44.
} 
So much for D's 'in-principle' culpability. Now consider the extent of D's culpability in the cases in which she is culpable in principle (as per Cases 5 to 12). As previously argued, we can plausibly say that $D$ is more culpable if it is her purpose to bring about $\alpha$, than if she brings about $\alpha$ knowingly but without it being her purpose to do so. Accordingly, because it was actually D's purpose that $\alpha$ occur in Cases 5, 6, 7, 8, 9, and 10, in those instances, D should be liable to be convicted of the full offence related to purposefully bringing about $\alpha$. In Case 11, D is indifferent to whether $\alpha$ occurs and in Case 12, D is probably averse to $\alpha$ occurring. In both cases however, she knows that her aid will facilitate the occurrence of $\alpha$. Although doctrine usually treats $\mathrm{D}$ as being equally culpable in these cases too, there is at least a plausible theoretical argument to be made for treating D slightly more leniently when it is not her purpose to bring about $\alpha{ }^{80}$ That intuition was probably in evidence in the House of Lords' willingness to extend the duress defence to the defendant in Lynch, ${ }^{81}$ and also in the debate amongst commentators sparked off by the outcome in NCB $v$ Gamble. ${ }^{82}$ In that case, the National Coal Board's weighbridge clerk recorded the weight of a lorry (as was his job), and allowed P, a lorry driver, to leave the coal board's premises with an overloaded (and therefore not road-legal) lorry. Although the clerk's only interest was in doing his job, he knew that P would violate the law, and was therefore an accessory to P's offence. Glanville Williams criticised this ruling, arguing that the law should not convict persons whose sole contribution to an offence was that they performed their normal duties. ${ }^{83}$ Although I doubt Williams' conclusion, it is certainly plausible to argue that D was not as culpable as someone whose purpose it was that $\mathrm{P}$ drive illegally. Moreover, if reduced convictions for the principal's offence were available, a stronger case could be made for not awarding unfortunate accessories (such as Lynch ${ }^{84}$ ) the mandatory life sentence when their principals committed murder, without disturbing the strict rule on duress laid down in Howe ${ }^{85}$ Courts could then also differently sentence the mafia boss who orders $\mathrm{P}$ to kill $\mathrm{V}$, and the babysitter who minds P's infant while P is doing the killing.

It seems then that the foregoing account of responsibility provides a helpful explanation of the manner in which we hold accessories liable for offences. It corresponds closely enough to doctrinal law to be plausible, but still offers us the philosophical purchase

\footnotetext{
${ }^{80}$ The Law Commission, in Law Com No 305 (n 48) para 3.79, favoured moderating the outcome in such cases and imposing inchoate, but not accessorial, liability.

${ }^{81}$ Lynch (n 73). S, on being threatened with execution, drove IRA terrorists on an 'expedition' to kill a policeman. Although charged as an accessory to murder, he was allowed to plead duress in defence. This ruling has since been overruled in Howe (n 53), and duress may no longer be pleaded as a defence to murder.

82 [1959] 1 QB 11.

${ }^{83}$ Glanville Williams, Criminal Law: The General Part (2nd edn, Stevens \& Sons 1961) 371-4; Simester \& Sullivan (n 50) 231-5.

${ }^{84}$ Lynch (n 73).

${ }^{85}$ Howe (n 53).
} 
to make suggestions for doctrinal reforms. In particular, it suggests that doctrine ought to differentiate between culpable in-principle secondary parties who want to bring about a proscribed occurrence, and those are either indifferent, or averse, to its happening.

One concern with implementing this suggestion is that it might compromise what the Law Commission calls the 'forensic advantage' of secondary liability-the option of convicting $\mathrm{D}$ of an offence even if the prosecution cannot prove whether, in participating in it, D was a principal offender or a secondary party (provided it can prove that $\mathrm{D}$ was one or other). ${ }^{86}$ The poster-case for this forensic advantage is Giannetto, ${ }^{87}$ in which it was clear that D's wife had been killed by either D or a hitman that D hired, but it was unclear which. Since the law of accessorial liability treats principals and accessories alike by default, the prosecution had the 'forensic advantage' of being able to secure a well-deserved murder conviction for D, even though the direct perpetrator could not be identified. The Law Commission was keen to retain this forensic advantage and it is easy to see why. However, we need not treat all accessories and principals alike by default in order to maintain the forensic advantage. Analysing the facts of Giannetto in terms of the account of accessorial responsibility described here, $\alpha$ (the death of D's wife) could certainly be attributed to D either as the direct perpetrator or as a secondary party on the basis that he either caused $\alpha$ himself, or procured the hitman to cause $\alpha$. If $\mathrm{D}$ was the direct perpetrator, then he was certainly culpable. He chose to flout the criminal law's advance guidance, $\beta$, against engaging in conduct aimed at causing $\alpha$, with the intention of causing $\alpha$. Hence, D could be convicted of murder. If $\mathrm{D}$ was the secondary party, then he $\mathrm{D}$ intentionally procured the hitman to engage in certain conduct, intending that the conduct violate $\beta$, and with the purpose of thereby causing $\alpha$. Here too, D would be liable to be convicted of full offence of murder. The forensic advantage in cases like Giannetto is preserved.

Admittedly, there may be some cases in which differentiating between culpable accessories on the basis of their commitment to bringing about $\alpha$ might lead to some loss of the forensic advantage. For instance, imagine that we know that one of D1 or D2 is the direct perpetrator who acted with the purpose of bringing about $\alpha$, and that the other is an accessory who knowingly assisted the direct perpetrator in bringing about $\alpha$ while being indifferent or averse to $\alpha$ 's occurrence. If the substantive offence carries different labels and punishments for purposefully bringing about $\alpha$, and for knowingly (but not purposefully) bringing about $\alpha$, then we cannot convict D1 and D2 as if they both wanted to bring about $\alpha$. It is difficult to conceive of any realistic scenario in which such a case might arise, but even if these facts arise in a case, it would certainly be possible to convict both D1 and D2 of the 'knowing' 
offence, since a person who purposefully brings about $\alpha$ also does so knowingly. It is unlikely that having to convict a one-in-a-million 'purposeful' party of a 'knowing' offence would be too great a price to pay for being fairer to the vast majority of accessories.

None of these arguments amount to a conclusive case for always convicting accessories of variegated offences depending on their personal commitment to bringing about the occurrence. It is possible that in some cases, overriding policy concerns such as the need to offer special protection to a particularly vulnerable classes of victims might dictate otherwise might dictate otherwise, in respect of some substantive offences. Nevertheless, it does supply a positive reason in support of such a reform of the law.

On balance, then, the philosophically enriched model of accessorial liability put forward in this paper offers a philosophically grounded exegesis of much of the existing doctrinal law relating to accessorial liability. Where it diverges from doctrine, the model generates liability outcomes that are plausible, fairer than those generated under existing law, and consistent with the principles of criminal responsibility that we find instantiated by the rules applicable to principal offenders. In doing so, it offers theoretically sound suggestions for reform, without the pitfalls of being radically revisionist.

\section{F. Concluding Thoughts}

In this paper, I aimed firstly to provide a better exegesis of the English doctrine on criminal accessorial liability, and secondly to offer plausible suggestions for doctrinal reform.

I did so by demonstrating how the English law of accessorial liability relates to the deeper principles underpinning the English criminal law's overall approach to criminal responsibility. In that exercise, I found it useful to distinguish responsibility in the sense of the authorship of an occurrence (attribution responsibility), from responsibility in the sense of praiseworthiness or blameworthiness for bringing about that occurrence (accountability responsibility). To hold a person criminally responsible for an occurrence as an accessory we need both, but only after establishing attribution does it makes sense to consider accountability.

An examination of the rules relating to principals and accessories in English criminal law reveals that they operate similarly (though not identically) in respect of attribution responsibility. For instance, the extent to which an agent's action influences consequence elements of the occurrence is relevant to attribution for both direct perpetrators and secondary parties. However, to be a direct perpetrator, one needs to be at least a necessary cause of the occurrence, whereas one can be a secondary party even by virtue of being a concurrent cause of the occurrence, or by influencing its likelihood. These differences are apt, and are 
necessitated by differences in the capacity in which the occurrence is attributed to the agent. I therefore concluded that the rules of attribution responsibility for secondary parties are broadly compatible with those relating to direct perpetrators, and with the principles underlying the English law's general approach to criminal responsibility.

There is a greater divergence in the English criminal law's approach to accountability responsibility for principals and for accessories. While variegated liability judgments are frequently made in respect of principals depending on their commitment to bringing about the proscribed occurrence, they are only exceptionally made in respect of accessories. Principled argument would suggest that the liability of accessories too ought to depend on their commitment to bringing about the proscribed occurrence. I demonstrated what a model of criminal accessorial liability that did so would look like by showing how it would deal with a series of subtly different cases. I relied on the plausibility of the liability outcomes generated by such a model for additional support for my arguments, and to pinpoint desirable clarifications and improvements in doctrine. In particular, I suggested that:

1. it be clarified that persons who had no influence on the occurrence perpetrated by the principal cannot be accessories irrespective of their personal levels of culpability, since the occurrence cannot be attributed to them; and

2. there is good (albeit not conclusive) reason to reform the doctrinal law of accessorial liability such that accessories are convicted of variegated offences depending on their personal commitment to bringing about the occurrence.

The adoption of these reforms into the English criminal law of accessorial liability would not be radically revisionist, and would make the law's general approach to criminal responsibility clear, principled, and fair. 